\title{
EXPERIENCE OF EMPLYING EXTRACORPORAL SHOCK-WAVE THERAPY FOR TREATING LIMB ENTHESOPATHIES IN PATIENTS WITH ARTICULAR HYPERMOBILITY SYNDROME
}

\author{
Vorotnikov A. A., Saneyeva G. A., Tsymbal A. N.
}

\section{Stavropol State Medical University, Russian Federation}

U pper and lower limb enthesopathy is a pathology associated with aseptic inflammation in tendons, fascia, and ligaments at the points of their attachment to bones [2]. The clinical symptoms include pain and sometimes local edemas at the lesion, which expands significantly in case of tension to the affected musculo-skeletal systems caused by routine or sports load, while all this affects the life quality in the patients.

The following are mentioned as the underlying factors of enthesopathy: physical overload, orthopedic deviations, traumas, and inflammatory diseases. In the recent years the respective scientific circles also have pointed at articular hypermobility syndrome (AHS) as one of the manifestations of connective tissue dysplasia, which is said to have a role in the development of limb enthesopathy $[4,6]$.

The most efficient in terms of stopping the pain syndrome caused by enthesopathy are considered to be nerve block therapies employing corticosteroids $[5,7]$. Given that, many patients, within different periods of time after the treatment is over, develop a relapse. Steroids also stand behind some side effects in patients (exacerbated stomach ulcer, osteoporosis progress, local pyoinflammatory complications, etc).

The latest decade has witnessed increasing interest in extracorporal shock-wave therapy (ESWT) for treating enthesopathies especially in case the patient has burdened somatic status, contraindication for steroid nerve block therapies, and nonsteroidal anti-inflammatory drugs (NSAIDs). Yet, despite the wide use of ESWT as of today there is no evidence concerning the clinical efficiency of this method if employed for treating limb enthesopathies combined with articular hypermobility syndrome; besides there is no evidence as to its efficiency along with other treatments and drugs.

Vorotnikov Alexander, MD, PhD, Professor, Head of department of traumatology and orthopedy, Stavropol State Medical University; tel.: $+7(8652) 716309$

Saneeva Galina, MD, Senior Lecturer of department of endocrinology, pediatric endocrinology and diabetology, Stavropol State Medical University;

tel.: + 79624500540; e-mail: sun-stav@yandex.ru

Tzimbal Andrey, traumatologist-orthopedist of Stavropol Clinical Diagnostic Center

tel.: +79624017272; e-mail: thimbal@rambler.ru
Purpose: to study the efficiency of extracorporal shock-wave therapy and the affected area orthopedic relief for treating pain syndrome associated with enthesopathies in patients with articular hypermobility syndrome.

Material and Methods. 75 patients with enthesopathies of various localizations and diagnosed articular hypermobility were observed (2008-2011) at the Consulting-Diagnostic Department of the Stavropol Regional Clinical Consulting-Diagnostic Centre (Table).

Morbidity patterns for limb enthesopathies

\begin{tabular}{|l|c|c|c|c|c|c|}
\hline \multirow{2}{*}{ Disease } & \multicolumn{4}{|c|}{ Number of patients $(\mathrm{n}=75)$} \\
\cline { 2 - 8 } & \multicolumn{2}{|c|}{ Males } & \multicolumn{2}{c|}{ Females } & \multicolumn{2}{c|}{ Total } \\
\cline { 2 - 7 } & Abs. & $\%$ & Abs. & $\%$ & Abs. & $\%$ \\
\hline $\begin{array}{l}\text { Lateral } \\
\text { epicondylitis }\end{array}$ & 16 & 21.3 & 5 & 6.7 & 21 & 28 \\
\hline $\begin{array}{l}\text { Medial } \\
\text { epicondylitis }\end{array}$ & 4 & 5.3 & 8 & 10.7 & 12 & 16 \\
\hline Plantar fasciitis & 10 & 13.3 & 32 & 42.7 & 42 & 56 \\
\hline
\end{tabular}

The patients' age varied between 35 and 55 years (median age being $37.5 \pm 0.4 \mathrm{yrs}$ ). The duration of the pain syndrome from the onset (irrespective of the localization) was: 1-3 months - in 20 (26.7\%) patients; 3-6 months - in 36 (48\%) patients, and over 6 months - 19 (25.3\%) patients.

All the patients went through the standard X-ray examination - in two projections for the elbow joint, and side view for the foot. Most cases revealed radiological manifestations of enthesopathies: osteophyte was found in 42 patients (56\%); local osteosclerosis - in 64 (85.3\%) patients, which was evidence of a longer history of the pathology.

Articular hypermobility was detected based on the Brighton diagnostic criteria [10] as modified by A. G. Belenky [1], where articular hypermobility was mapped following the Beighton scale [9] offering a 9-point measurement for the patient's ability to perform five movements - four for the limbs and one - for the body and the hip joint. The movement amplitude in joint limbs was evaluated following the expanded standard scheme used for most examinations in the area of traumatology \& orthopedics. 
To investigate the clinical efficiency of extracorporal shock-wave therapy for articular hypermobility syndrome there was a clinical study conducted where 75 patients with enthesopathies were stratified into three groups; the differences among the three being not significant enough to have an impact on the treatment outcome. Each of the groups included 25 patients. In Group 1 the patients were treated with extracorporal shockwave therapy alone; in Group 2 extracorporal shock-wave therapy was combined with elbow or ankle-joint orthoses and a protective regimen for the period of treatment. The remaining twenty five patients underwent therapy with nonsteroidal antiinflammatory drugs both per os, and locally for 10 days, combined with the orthoses on the impaired limb segment.

The treatment was out-patient, with a shockwave device PIEZOSON-100 (by RICHARD WOLF).

The procedure implied no ultrasound navigation, while the therapeutic head was positioned straight at the affected areas. The therapeutic heads used had their active focus diameter at $5 \mathrm{~mm}-25 \mathrm{~mm}$. The number of the impulses per one session was 3.000 ; with a frequency of $4 \mathrm{~Hz}$. Depending on the pain syndrome intensity the energy level was adjusted manually, varying from 1 to 20 . The duration of the session was 12-17 min; average number - 5; repetition - 1 per 7 days.

The clinical observation was done straight after the fifth session of extracorporal shock-wave therapy to be repeated further again 3 and 6 months after. The treatment efficiency was assessed with the Numerical Rating Scale (NRS) including 11 points - from 0 («no pain») to 10 («the worst pain you could ever imagine») [8].

The statistical analysis of the clinical data was performed with the Statistica-7 software and MS Excel 2009 spreadsheets.

Results. An analysis of pain in the 25 patients of Group 1 prior to the treatment showed that its intensity (by NRS scale) was $7.6 \pm 0.3$ points. In Group 2 the pain rated at $7.2 \pm 0.2$ points. In Group 3 the rate of the pain syndrome by the NRS scale came up to $7.4 \pm 0.6$ points (Fig. 1).

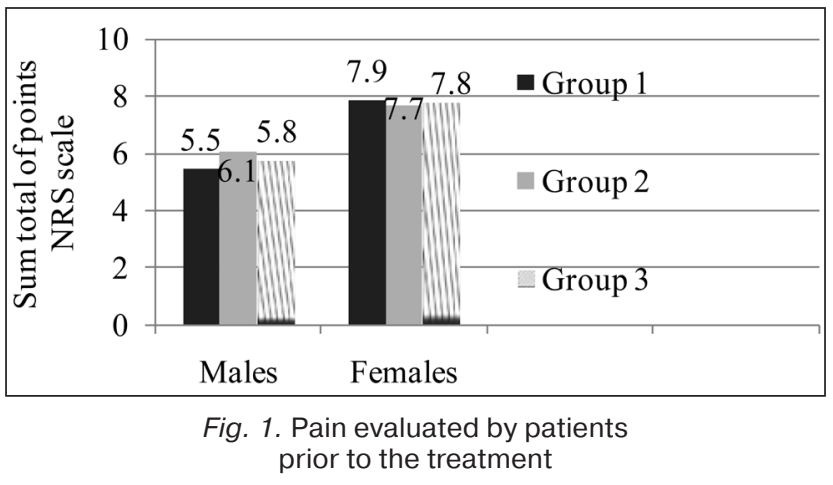

When treated with extracorporal shock-wave therapy the patients of Group 1 and Group 2 showed reduced intensity of the pain (Fig. 2).

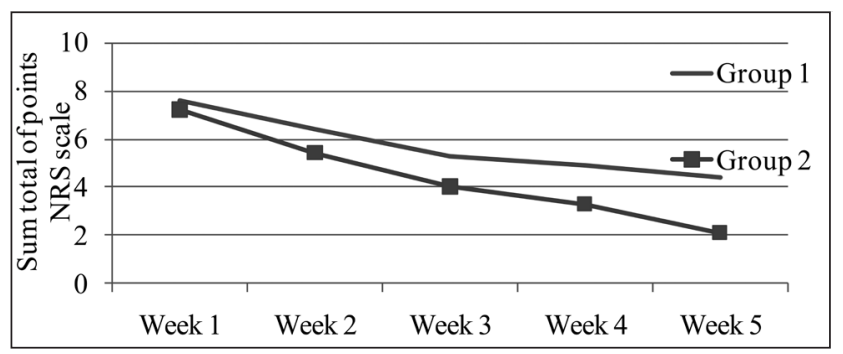

Fig. 2. Pain relief dynamics through the ESWT course

Figure 3 shows the dynamics observed in the patients of Group 3 treated with NSAIDs.

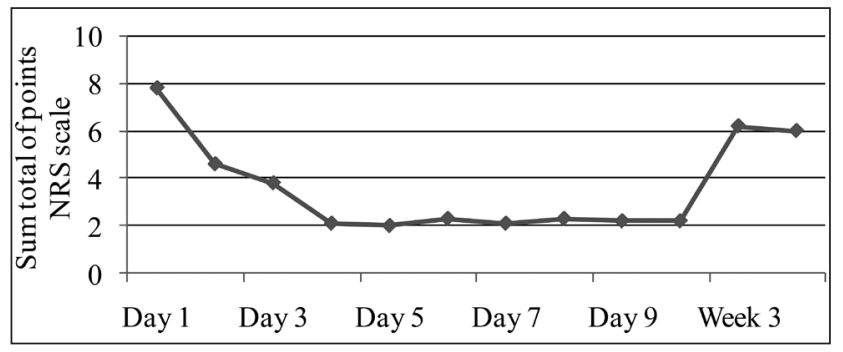

Fig. 3. Dynamics of pain syndrome relief in Group 3 through the treatment with NSAIDs

None of the 75 patients revealed any clinically meaningful complications (general or local) when going through extracorporal shock-wave therapy through the study. 10 (13.3\%) patients had higher intensity of the pain syndrome after the first session, which went down with no specific measure taken 3-4 days later. Some edema was observed in the treated area in $6(8 \%)$ patients for $5-7$ days.

The final outcomes after six months from the start of the treatment can be seen in Figure 4.

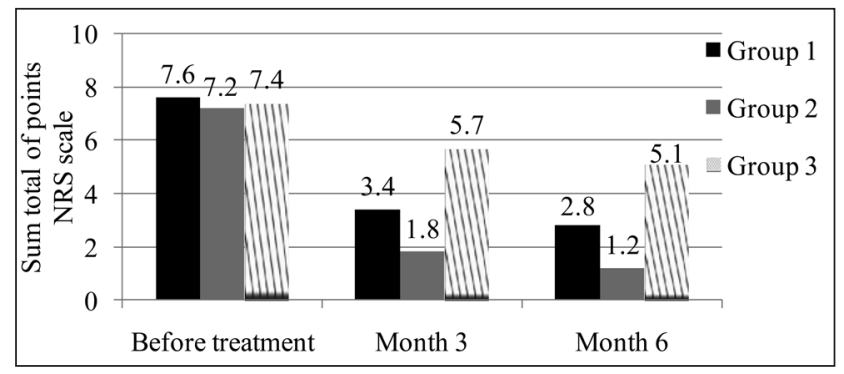

Fig. 4. Pain syndrome dynamics on Month 6 of treatment

Discussion. An analysis of the data obtained has shown an advantage of ESWT combined with orthopedic relief if compared with NSAIDs when used for treatment of pain syndrome due to limb enthesopathies. The relief dynamics for the pain syndrome on Month 6 was $63.1 \%$ in Group 1, $83.3 \%$ - in Group 2, and $31 \%$ - in Group 3. An obvious advantage of ESWT was the out-patient treatment mode, lack of invasion, lack of local and general complications, and a short course of treatment.

Conclusion. The results of treatment for pain syndrome associated with limb enthesopathies serve 
proof of a high clinical efficiency, safety, and reliability of extrascorporal shock-wave therapy in this case. This method of treatment also allows overcoming troubles in treating patients with contraindication for nonsteroidal anti-inflammatory drugs and nerve block therapies with hormonal drugs.

\section{References}

1. Belenky G. A., Maslova E. S. Clinical variants in articular hypermobility syndrome manifestations - age aspect. Clinical Medicine. 2002;4:42-45.

2. Bunchuk N. V., Nasonova V. A. Diseases in extraarticular soft tissues. Manual on internal diseases. Rheumatic diseases. M.: «Medicine»; 1997. P. 411-439.

3. Viktorova I. A., Kiseleva D. S., Kalitskaya I. G. Articular hypermobility: effect of excessive physical stress on development of pain syndrome. Medical Newsletter of North Caucasus. 2008;2:105-107.

4. Godzenko A. A. Treatemnt of periarticular pain syndromes. Russian Medical Journal: Rheumatology. 2012;7:382-385.

\section{EXPERIENCE OF EMPLYING EXTRACORPORAL SHOCK-WAVE THERAPY FOR TREATING LIMB ENTHESOPATHIES IN PATIENTS WITH ARTICULAR HYPERMOBILITY SYNDROME \\ VOROTNIKOV A. A., SANEYEVA G. A., \\ TSYMBAL A. N.}

Purpose: to study the efficiency of extracorporal shock-wave therapy and the affected area orthopedic relief for treating pain syndrome associated with enthesopathies in patients with articular hypermobility syndrome.

75 patients with enthesopathies of various localizations and diagnosed articular hypermobility were observed in 2008-2011, their age varying from 35 to 55 years (median age: $37.5 \pm 0.4$ years). The treatment mode was out-patient, with a shockwave device PIEZOSON-100 (manufacturer: RICHARD WOLF). The clinical observation was done straight after the $5^{\text {th }}$ session of extracorporal shock-wave therapy, and then 3 and 6 months after. The treatment efficiency was evaluated using the Numerical Rating Scale (NRS). Besides, the whole course of treatment included protective regimen, as well as elbow or ankle-joint orthoses.

The positive outcomes obtained after treating the pain syndrome associated with limb enthesopathies serve evidence to the efficiency of extracorporal shock-wave therapy, which, in case of articular hypermobility syndrome present as well, should be combined with an orthopedic relief for the affected limb area.

Key words: extracorporal shock-wave therapy, enthesopathy, articular hypermobility syndrome
Extracorporal shock-wave therapy together with orthopedic relief in the affected limb area allows improving the life quality, within optimal time, for patients suffering from limb enthesopathies with articular hypermobility syndrome.

5. Mironov S. P., Kotelnikov G. P. Orthopedics: national guide. M.: «GEOTAR-Media»; 2008. 832 p.

6. Mitskevich V. A., Arseniev A. O. Podiatry. M.: «BINOM»; 2006. $136 \mathrm{p}$

7. Ter-Vartanyan S. Kh., Yaremenko O. B., Khudina V. S. Local injection therapy for impaired joint and periarticular tissues. Kiev: «Kniga-Plus»; 1997. 139 p.

8. Breivik H. et al. Assessment of pain. British Journal of Anaesthesia. 2008;1(101):17-24.

9. Beighton P., Solomon L. , Soskolne C. L. Articular mobility in an African population. Ann. Rheum. Dis. 1973;32:413-418.

10. Grahame R., Bird H. A., Child A. The revised (Brighton, 1998) criteria for the diagnosis of benign articular hypermobility syndrome (BJHS). J. Rheum. 2000;7(27):1777-1779.

\section{ОПЫТ ПРИМЕНЕНИЯ ЭКСТРАКОРПОРААЬНОЙ УААРНО-ВОАНОВОЙ ТЕРАПИИ В АЕЧЕНИИ ЭНТЕЗОПАТИЙ КОНЕЧНОСТЕЙ У ПАЦИЕНТОВ С СИНАРОМОМ ГИПЕРМОБИАЬНОСТИ СУСТАВОВ}

А. А. ВОРОТНИКОВ, Г. А. САНЕEВА,

А. Н. ЦЫМБА^,

Цель работы: изучить эффективность лечения болевого синдрома при энтезопатиях конечностей у пациентов с синдромом гипермобильности суставов методом экстракорпоральной ударно-волновой терапии с ортопедической разгрузкой пораженного сегмента конечности.

За период 2008-2011 годов наблюдались 75 пациентов с энтезопатиями конечностей в сочетании с синдромом гипермобильности суставов. Возраст варьировал от 35 до 55 лет

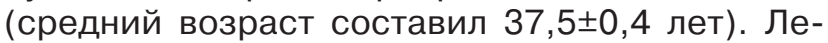
чение осуществляли амбулаторно на ударноволновой установке ПЬЕЗОСОН-100, фирмы «RICHARD WOLF». Клиническое наблюдение проводили непосредственно с окончанием 5 процедуры экстракорпоральной ударно-волновой терапии, затем через 3, 6 месяцев. Оценивали эффективность лечения по цифровой рейтинговой шкале боли (Numerical Rating Scale, NRS). Дополнительно на весь курс лечения назначали лечебно-охранительный режим, ортезирование локтевого или голеностопного суставов.

Положительные результаты в лечении болевого синдрома при энтезопатиях конечностей свидетельствуют о высокой клинической эффективности экстракорпоральной ударно-волновой терапии, которую необходимо дополнять при сочетании с синдромом гипермобильности суставов ортопедической разгрузкой пораженного сегмента конечности.

Ключевые слова: экстракорпоральная ударно-волновая терапия, энтезопатия, синдром гипермобильности суставов 